\author{
E. V. Boldanova, N. P. Bakalenko
}

\title{
Concession agreements as a means of attracting investment in transport infrastructure
}

\author{
KEYWORDS \\ concession agreements; \\ public-private partnerships; \\ infrastructure; \\ transport; \\ investment; \\ efficiency \\ balance
}

\section{ABSTRACT}

The relevance of the research topic is due to the need to ensure adequate investment for the development of transport infrastructure. State funds cannot provide for investment flows. The most flexible tool for attracting private capital is a public-private partnership in the form of concession agreements. Unfortunately, there is no standard methodology to assess the effectiveness of a public-private partnership project, which is a prerequisite for participation in a public-private partnership.

The assessment of the current market for public-private partnership projects is based on statistical analysis methods. The study revealed an increasing role of public-private partnership in the development of transport infrastructure. The author compares the existing methods for assessing the effectiveness of public-private partnership projects using comparative analysis methods. The evaluation methods do not provide for assessing compliance with the deadlines and quality of project facilities or services provided; they lack verification for the classical balance between price, timing, and quality. Further research might focus on direct and indirect effects from the development of infrastructure based on multicriteria decision-making and balance methods.

Boldanova, E. V., \& Bakalenko, N. P. (2020). Concession agreements as a means of attracting investment in transport infrastructure. Economic consultant, 29 (1), 4-11. doi: 10.46224/ecoc.2020.1.1 


\section{INTRODUCTION}

G

overnment authorities cannot adequately finance the maintenance and development of infrastructure in general and railway infrastructure in particular. This is true not only for Russia but also for the rest of the world. The experience of foreign countries indicates that the mobilization of private sector investment is one of the effective alternatives for development. However, such mobilization implies using concession agreements and projects instead of privatization.

A new institutional environment based on a partnership between the state and private business has been forming since the early 1990s. The benefits of development in a market environment are becoming available to industries with strong state influence. Public-private partnership (PPP) is implemented primarily in the form of concessions.

Various publications have been published on PPPs and concessions. The World Bank made a significant contribution to the development of the theoretical base. Several national and international PPP research centers have been created worldwide: the National Bureau of Research (Cambridge), the Center for Global Infrastructure (Sydney, Toronto), and the National Center for PPP (Moscow).

The issues of interaction between state and private capital were considered in domestic and foreign literature, including in the analysis of the relationship between the roles of authorities and PPP forms (Metcalfe and Lapenta [21]), assessment of differences in the financial condition of public-private enterprises and fully state-owned enterprises (Monteduro [22]), the impact of the transaction costs economy on the concept of public administration in the transport system (Canonico et al. [15]), concession issues in transport (Varnavskii [7]), the issues of correlation of concession and franchising agreements (Vronskaya and Amaryan [8]).

The problems of assessing the economic efficiency of concession contracts were considered in the works of Tang and Lo [23], Kabasakal et al. [18], Eganyan [10]; Belikov examined the assessment of investment potential [5]. Other authors also studied the use of critical success factors for adapting PPP projects (Kulshreshtha et al. [19]), structural modeling (Lun et al. [20]), mathematical modeling for assessing economic and technical parameters (Christakos and Kalfakakou [16]), the influence of logistic factors and technologies (Kolodin [11, 12]), geopolitical changes (Korodyuk [13, 14]), and the analysis of socio-economic growth factors (Bylkov [6]).

Further disclosure of the PPP possibilities to attract investment in transport infrastructure requires considering the methods used to assess the effectiveness of concession contracts. It is the choice of the concessionaire and the conclusion of the contract that determine the future outcome of the interaction between the state and private capital. 


\section{MATERIALS AND METHODS}

Legal documents of the Russian legislation, the World Bank's statistical reporting [9] and the data of the National Center for PPP [17] served as research materials. To compare the existing methods for assessing investment PPP projects, the authors used comparative analysis methods with numerous criteria. To analyze the dynamics of investment in infrastructure, the researchers used methods of statistical analysis: analysis of statistical averages, correlation and regression analysis.

\section{RESULTS}

According to experts, losses due to infrastructural insecurity account for $10-20 \%$ of the Russian GDP annually.

At the same time, the largest volumes of extrabudgetary funding through the PPP mechanism is spent on the transport industry, namely road networks.

It is believed that the lifting of certain restrictions results in demand for the railway, port, airport, and other transport sectors.

Several Russian and foreign experts state that the railway sector can place a request for extra-budgetary projects in the amount of 10-20 billion US dollars annually for several years. However, due to numerous restrictions, this amount cannot be received in the nearest future.

According to the World Bank, in 2018, the transport sector outstripped the energy sector in terms of investments for the first time in 10 years. Nearly $60 \%$ of global PPP investments are directed to transport. This is primarily due to the significant increase in investments in China, India, and Turkey - their road projects have received the highest investment. Changes in the Chinese and Indian PPP regulations prompted the private sector to invest in infrastructure projects in the transport sector.

Based on World Bank data on income-aggregated groups of countries, the authors assessed the dependence of the PPP share of investments in transport in the volume of GDP $\left(\mathrm{I}_{\mathrm{tr}}\right)$ on the average per capita GDP (GDP):

$$
\mathrm{I}_{\mathrm{tr}}=0.1012 \cdot \mathrm{GDP}^{-0.511}, \mathrm{R}^{2}=0.9925
$$

With an increase in per capita income, the share of PPP investments decreases and stabilizes at one level. In absolute terms, investment in infrastructure grows proportionally to the growth of per capita income.

Russian economic reality has its own specifics. The capacity of its own financial system is insufficient to maintain the investment climate of PPPs. The analysis of PPP investment in transport infrastructure shows a significant increase before 2010. However, over the past five 
years, these volumes have halved. This negative trend is due to numerous factors, not only economic but also political. This problem can be solved by attracting Russian and foreign private capital.

There are prospects for using Chinese investment. However, considering the upcoming financial and economic crisis due to coronavirus, this might be a big question.

At the same time, China is the absolute leader in PPP investments in general and in transport infrastructure in particular (World Bank data for 2017). In terms of PPP investments in transport, China is followed by Indonesia, India, Thailand, and the Russian Federation. Russia's contribution to the global volume of PPP investment is about 5.5\% (according to the World Bank).

The attraction of private capital for participation in PPP projects is regulated by internal legislation that describes the choice of a concessionaire based on the assessment of an investment project. The authors conducted a comparative analysis of existing methods and guidelines for evaluating investment projects implemented as part of PPPs, concessions, as well as those applying for state funding (Order of the Ministry of Economic Development of the Russian Federation of December 14, 2013 No. 741 [1]; Order of the Ministry of Transport of the Russian Federation of September 8, 2014, No. 1714-r [2]; Order of the Ministry of Economic Development of the Russian Federation of November 30, 2015 No. 894 [3]; Order of the Ministry of Transport of the Russian Federation of August 01, 2016 No. 221 [4]).

Almost all methods are based on a standard financial model that allows assessing the financial effectiveness of a project. In some cases, a single scheme is used to assess the effectiveness of the project as a whole, the efficiency of equity and budgetary effectiveness. All methods involve the calculation of the net present value.

There is no unity in approaches to assessing budgetary effectiveness. However, in most cases, they use the budgetary performance indicator and the budgetary net present value.

Most difficulties occur when assessing socio-economic efficiency: monetizing non-market effects, calculating macroeconomic effects. Furthermore, some approaches suggest calculating credit stability, evaluate risks, and compare with similar objects.

Such calculations should result in the definition of a comprehensive, integrated assessment in the form of a total point score or rating.

The comparative analysis of assessing methods in terms of multiple criteria of financial, budgetary and socio-economic efficiency concluded that the most complete and universal method was proposed in the Order of the Ministry of Economic Development No. 741. However, one must consider the potential outcomes of these methods.

\section{DISCUSSION}

All the methods discussed above do not imply an assessment of compliance with the specified time frame and quality for project facilities or services provided. Order No. 894 
explicitly states that in determining comparative advantages one must not consider the quality of public services, innovative solutions, and delivery times. All of this translates into failure to comply with the classic balance between price, timing, and quality.

The results of applying the investment project assessment solely at the initial stage of investment can be seen from the example of other countries where this practice has existed for a long time. In the end, the concessionaire who offers the smallest sum wins, which does not always mean the best choice. This fact can be explained by the theory of declining choices. Therefore, the existing methods for assessing the effectiveness require further development to overcome the prevailing negative consequences. The effectiveness of the project should be evaluated throughout the life cycle. Besides, one must constantly monitor quality records and construction deadlines.

Decision-making in a multi-criteria environment is a complex task that requires multiple approaches. Using the final integral estimate does not always lead to an unconditional decision. When considering projects contrasting in terms of the price-quality-cost ratio, it might be useful to consider the Edgeworth-Pareto principle. Foreign authors suggest using a gaming approach. Furthermore, the selected form of PPP also affects the assessment of the effectiveness of the PPP project.

\section{CONCLUSION}

Over the past 10 years, the existing dynamics of the PPP investment in the Russian transport infrastructure illustrates a twofold decrease in activity. The intensification of the PPP in infrastructure sectors requires further refinement of methodology for assessing the effectiveness of public-private investments. When considering large infrastructure projects, it is necessary to assess all outcomes, including direct and indirect, not only cost indicators but also qualitative ones. Moreover, one must consider the chosen form of PPP.

Further efforts should be aimed at developing a complex assessment of direct and indirect outcomes from the project implementation. To address this challenge, the authors suggest using multicriteria decision-making methods, as well as balance methods.

\section{REFERENCES}

1. Order of the Ministry of Economic Development of the Russian Federation No. 741 "On the Approval of Guidelines for the Preparation of Strategic and Comprehensive Justifications for an Investment Project, as well as for the Assessment of Investment Projects Applying for Financing from the National Welfare Fund and (or) Pension Savings Held in Trust Management of a State Management Company, on a Return Basis". (2013, December 14). Retrieved March 4, 2020, from https://www.consultant.ru/document/cons_doc_LAW_160381/ 
2. Order of the Federal Road Agency No. 1714-r "On the Approval of Guidelines for Structuring an Investment Project for the Possibility of Applying Various Investment Mechanisms, Including Public-Private Partnership, the Guidelines for Assessing the Efficiency of InvestmentMechanisms, Including Public-PrivatePartnership, the Guidelines for Selecting Optimal Investment Mechanisms, Including Public-Private Partnership Mechanisms, in Implementation of Investment Projects". (2014, September 8). Retrieved March 4, 2020, from http://www.consultant.ru/document/cons_doc_LAW_256410/

3. Order of the Ministry of Economic Development of the Russian Federation No. 894 "On the Approval of Guidelines for Assessing the Effectiveness of a Public-Private Partnership Project, a Municipal-Private Partnership Project and Determining Their Comparative Advantage". (2015, November 30). Retrieved March 4, 2020, from http:// www.consultant.ru/document/cons_doc_LAW_192148/2ff7a8c72de3994f30496a0ccb b1ddafdaddf518/

4. Order of the Ministry of Transport of the Russian Federation No. 221 "On the Approval of Guidelines for the Selection of Construction Projects (Reconstruction) of Roads (Road Sections and (or) Artificial Road Structures) Implemented by the Constituent Entities of the Russian Federation under Concession Agreements, to Provide Other Inter-Budget Transfers to Achieve the Targets of the Regional Programs in the Field of Road Maintenance Providing for the Implementation of These Projects". (2016, August 1). Retrieved March 4, 2020, from http://www.consultant.ru/document/cons_doc_LAW_203276/

5. Belikov, A. Y. (2016). Comparative Analysis of Methods for Determining and Assessing the Investment Potential of an Economic Entity. Journal of the Baikal State University, 26 (5), 750-757.

6. Bylkov, V.G., \& Belobrova, E.A. (2016). Analysis of the Socio-Economic Factors of Labor Productivity Growth in Rail Transport. Transport infrastructure of the Siberian region, 2, 12-16.

7. Varnavskii, V.G. (2002). Concessions in Transport Infrastructure: Theory, Practice, and Prospects. Moscow: IMEMO RAS.

8. Vronskaya, M.V., \& Amaryan, L.A. (2017). Commercial Concession Agreement and Franchising Agreement: A Comparative Legal Analysis of Russian and International Legislation. The territory of New Opportunities, 4 (39). Retrieved March 4, 2020, from https://cyberleninka.ru/article/n/dogovor-kommercheskoy-kontsessii-i-dogovorfranchayzinga-sravnitelno-pravovoy-analiz-rossiyskogo-i-mezhdunarodnogozakonodatelstva

9. World Bank. (n.d.). Official Website. Retrieved March 4, 2020, from https://www. worldbank.org/

10. Eganyan, A. (2019). Investment in Infrastructure: Money, Projects, Interests. PPP, Concessions, and Project Financing. Moscow: Alpina publisher. Retrieved March 4, 2020, from http://www.iprbookshop.ru/82963.html

11. Kolodin, V.S., \& Bystritskaya, Y.M. (2015). Logistic Factors Affecting the Development of Russian retail. Bulletin of Irkutsk State Economic Academy, 25 (1), 95-102. 
12. Kolodin, V.S. (2011). Areas for the Cooperation of Marketing and Logistics Technologies in the Production and Physical Distribution of Products. Bulletin of Irkutsk State Economic Academy (Baikal State University of Economics and Law), 5. Retrieved March 4, 2020, from http://eizvestia.isea.ru/reader/article.aspx?id=9702

13. Korodyuk, I.S., Silantev, A.V., \& Davaasuren, A. (2019). Geopolitical Changes as an Incentive for the Integrated Development of Transport and Logistics Systems in Eastern Siberia and Mongolia. Bulletin of Baikal State, 29 (1), 72-79.

14. Bovkun, A.S., Korodyuk I.S., \& Arkhipkin O.V. (2018). Detection and Analysis of Model Construction of Innovative Development in Russian Regions. In The European Proceedings of Social \& Behavioural Sciences EpSBS (pp. 246-253).

15. Canonico, P., De Nito, E., Mangia, G. et al. (2013). Regulation Issues in the Italian Local Transport System: Aligning Transactions and Governance Structures. The Journal of Management and Governance, 17, 939-961. Retrieved March 4, 2020, from https:// doi.org/10.1007/s10997-011-9205-2

16. Christakos, E.K., \& Kalfakakou, G. (2007). An Economic Evaluation Model for Concession on Convention Infrastructure Projects in Greece. Operational Research, 7, 147-164. Retrieved March 4, 2020, from https://doi.org/10.1007/BF02941191

17.G20 IWG Report on the Results of the Survey on PPP Developments in the G20 Economies. (2019). Global Infrastructure Hub. Retrieved March 4, 2020, from https:// www.gihub.org/resources/publications/g20-iwg-report-on-the-results-of-the-survey-onpublic-private-partnership-developments-in-the-g20-economies/

18. Kabasakal, A., Kutlar, A., \& Sarikaya, M. (2015). Efficiency Determinations of the Worldwide Railway Companies via DEA and Contributions of the outputs to the efficiency and TFP by panel regression. The Central European Journal of Operations Research, 23, 69-88. Retrieved March 4, 2020, from https://doi.org/10.1007/s10100-013-0303-x

19. Kulshreshtha, R., Kumar, A., Tripathi, A. et al. (2017). Critical Success Factors in Implementation of Urban Metro System on PPP: A Case Study of Hyderabad Metro. The Global Journal of Flexible Systems Management, 18, 303-320. Retrieved March 4, 2020, from https://doi.org/10.1007/s40171-017-0164-6

20.Lun, Y.H.V., Carlton, J., \& Bichou, K. (2016). Examining the Economic Impact of Transport Complex Economies. Journal of Shipping and Trade, 1. Retrieved March 4, 2020, from https://doi.org/10.1186/s41072-016-0005-3

21. Metcalfe, L., \& Lapenta, A. (2014). Partnerships as Strategic Choices in Public Management. Journal of Management and Governance, 18, 51-76. Retrieved March 4, 2020, from https://doi.org/10.1007/s10997-012-9233-6

22. Monteduro, F. (2014). Public-Privateversus Public Ownershipand Economic Performance: Evidence from Italian Local Utilities. Journal of Management and Governance, 18, 29 49. Retrieved March 4, 2020, from https://doi.org/10.1007/s10997-012-9235-4

23. Tang, S., \& Lo, H.K. (2010). Assessment of Public-Private Partnership Models for Mass Rail Transit - an Influence Diagram Approach. Public Transport, 2, 111-134. Retrieved March 4, 2020, from https://doi.org/10.1007/s12469-010-0023-8 


\section{INFORMATION ABOUT THE AUTHORS}

1. Elena V. Boldanova (Russia, Irkutsk) - PhD in Economics, Associate Professor of Economics and Business Management Department. Baikal State University. E-mail: boldanova@mail.ru

2. Natalya P. Bakalenko (Russia, Novosibirsk) - Magistrate, Siberian Transport University. E-mail: bakalenko_n@mail.ru 